\title{
Pencitraan Hiperspekral untuk Membedakan Asal Tanah Tumbuh Dari Tandan Buah Segar Kelapa Sawit
}

\author{
Dina Veranita ${ }^{1}$, Minarni Shiddiq ${ }^{1}{ }^{*}$, Feri Candra ${ }^{2}$, Saktioto $^{1}$, Mohammad Fisal Rabin ${ }^{1}$ \\ ${ }^{1}$ Program Studi Magister Fisika, Universitas Riau, Pekanbaru, Indonesia \\ ${ }^{2}$ Fakultas Teknik, Program Studi Teknik Informatika, Universitas Riau, Pekanbaru, Indonesia \\ Email: ${ }^{1}$ dina.veranita@gmail.com, ${ }^{2,}{ }^{*}$ minarni@ unri.ac.id, ${ }^{3}$ feri@eng.unri.ac.id, ${ }^{4}$ saktioto@yahoo.com, \\ ${ }^{5}$ fisal.rabin25@gmail.com \\ Email Penulis Korespondensi: minarni@unri.ac.id
}

\begin{abstract}
Abstrak-Pencitraan hiperspektral merupakan metode nondestrukif yang dapat digunakan untuk mengevaluasi karakteristik internal buah dan sayuran. Sifat genetik tanaman, sifat tanah dan pengelolaan tanaman menentukan kualitas tandan buah segar (TBS) kelapa sawit. Penelitian ini bertujuan untuk membedakan TBS kelapa sawit yang berasal dari pohon yang tumbuh dari tanah mineral dan tanah gambut mengunakan pencitraan hiperspektral berdasarkan tingkat kematangan dan kekerasan buah. Sampel terdiri dari 61 TBS Varitas Tenera dari tanah mineral dan 60 TBS dari tanah gambut dengan tiga tingkat kematangan yaitu mentah, kurang matang dan matang. Sistem pencitraan hiperspektral dibangun mengunakan spektrograf Specim V10 dan sumber cahaya Lampu Halogen. Citra hiperspektral direkam dan diproses menggunakan program Matlab. Hasil penelitian menunjukkan perbedaan intensitas reflektansi spektrum pada rentang panjang gelombang 700-900 nm. Intensitas reflektansi TBS kelapa sawit dari tanah mineral lebih kecil dibanding dari tanah gambut. Tingkat kekerasan buah untuk TBS kelapa sawit matang dari tanah gambut lebih besar dari pada TBS kelapa sawit dari tanah mineral. Klasifikasi mengunakan K- mean clustering antara intensitas reflektansi dan kekerasan buah memperlihatkan pengelompokan yang signifikan untuk tiga tingkat kematangan baik untuk TBS tanah gambut maupun tanah mineral. Informasi ini berguna untuk pembuatan sistem sortasi TBS kelapa sawit mengunakan metode pencitraan spektral.
\end{abstract}

Kata Kunci: Pencitraan Hiperspektral, Kelapa Sawit, Tandan Buah Segar, Tingkat Kekerasan, K-Mean Clustering

Abstract-Hyperspectral imaging is a non destructive method that has been used to evaluate internal characteristics of fruits and vegetables. Plant genetics, soil characteristics, and plant management are some of key factors to define the quality of oil palm fresh fruit bunches (FFB) produced. This research was aimed to discriminate the Tenera oil palm FFBs produced by oil palm trees grown from mineral soil and peat soil using a hyperspectral imaging system which utilized a Specim V10 spektrograf. The discrimination was based on their ripeness level, mesocarp firmness, and classification using K-mean clustering. The samples consisted of 61 mineral soil FFBs and 60 peat soil FFBs with three ripeness levels as unripe, ripe, and overripe. Hyperspectral images were recorded and processed using Matlab programs. The spectral reflectance intensities showed the discrimination between both origin soils at wavelength ranges of $700 \mathrm{~nm} \square 900 \mathrm{~nm}$. The results also showed higher reflectance intensities of peat soil FFBs than mineral soil FFBs. Correspondingly, Fruit firmness of peat soil FFBs are higher than mineral soil FFBs. Classification using K- mean clustering between reflectance intensities and fruit firmness showed significant clusters for three ripeness levels. These results will be useful for an oil palm FFB sorting machine based on spectral imaging method.

Keywords: Hyperspectral Imaging, Oil Palm, Fresh Fruit Bunches, Firmness Level, K-Mean Clustering

\section{PENDAHULUAN}

Metode pencitraan adalah metode nondestruktif yang saat ini intensif diaplikasikan pada bidang pertanian khususnya untuk deteksi penyakit tanaman, deteksi kematangan sebelum panen, dan menentukan mutu produkproduk petanian seperti buah dan sayuran pascapanen. Metode pencitraan mengunakan kamera, komputer dan analisis citra disebut juga Computer Vision. Metode Computer vision adalah metode yang cepat, akurat, dan objektif [1], yang diharapkan dapat mengantikan metode manual dan tradisional yang masih di jumpai pada industri. Metode tradisional ini cenderung bersifat subyektif, membutuhkan pengalaman, lambat, dan tidak konsisten untuk pekerjaan yang banyak dan berulang [2].

Metode pencitraan Computer Vision konvensional di artikan sebagai metode pencitraan mengunakan kamera, komputer, sumber cahaya, dan sofware pengolah dan analisis citra Pada umumnya sistem tersebut mengunakan kamera warna dan sumber cahaya putih. Computer Vision konvensional dapat mengevaluasi karakteristik ekternal buah dan sayuran seperti warna, tekstur, bentuk dan ukuran [3]. Metode ini telah digunakan untuk deteksi kematangan dan kerusakan buah tomat secara otomatis [4] dan menjadi bagian dalam proses penyortiran dan penentuan kualitas buah kurma pasca panen secara otomatis mengunakan informasi warna Hue, Saturation, Value (HSV) [5].

Metode optik adalah metode deteksi mengunakan interaksi antara gelombang elektromagnetik dan material biologi seperti buah dan sayuran. Spektrum elektromagnetik meliputi gelombang radio, gelombang mikro, inframerah, cahaya tampak, ultraviolet, sinar-X, dan radiasi sinar gamma. Metode ini disebut juga metode spektroskopi karena berhubungan dengan panjang gelombang dimana informasi spektral dari buah yang dikenai cahaya dapat dianalisis. Karena kebutuhan akan informasi spektral dan spasial secara bersamaan, saat ini metode pencitraan Computer Vision tradisional diperluas dengan melibatkan interaksi antara cahaya dengan material biologi dalam hal ini buah dan sayuran. Interaksi yang terjadi tersebut dapat berupa reflektansi, absorpsi, fluoresensi, hamburan balik, dan transmisi cahaya oleh bagian ekternal maupun bagian internal buah bergantung 
pada sifat-sifat optik buah dan panjang gelombang cahaya yang terlibat [6]. Berdasarkan fenomena tersebut gabungan antara metode pencitraan dan spektroskopi yang disebut pencitraan spektroskopi atau Computer Vision spektral telah dikembangkan antara lain seperti pencitraan Raman, pencitraan hiperspektral, multispektral, pencitraan hamburan balik mengunakan laser [7]. Metode pencitraan lainnya juga telah dikembangkan untuk evaluasi kematangan buah dan sayuran seperti pencitraan nuklir magnetik (MRI), termal, dan pencitraan microwave, Metode -metode pencitraan ini diminati dan dipilih karena sederhana, respon waktu yang cepat, non invansif, dan dapat diandalkan [8].

Pencitraan hiperspektral dan multispektral adalah salah satu jenis metode pengabungan antara metode pencitraan dan spektrosopi yang disebut juga metode pencitraan spektral. Metode ini semula dikembangkan untuk pencitraan remote sensing, namun hampir dua dekade terakhir diaplikasikan sebagai teknik baru dan potensial untuk mengevaluasi kualitas dan keamanan makanan dan produk pertanian. Teknik ini memberikan informasi spektral dan spasial dari sampel, sehingga lebih informatif, dibandingkan teknik pencitraan Computer Vision atau spektroskopi konvensional [9]. Pencitraan Hiperspektral megunakan rentang panjang gelombang yang besar dengan jumlah pita panjang gelombang berkisar antara 100 - 500 band, dengan perbedaan panjang gelombang $5 \mathrm{~nm}<\Delta \lambda<10 \mathrm{~nm}$ sehingga mempunyai spektrum yang kontinius. Pencitraan multispektral mempunyai jumlah pita panjang gelombang lebih sedikit untuk tujuan praktis (kurang dari 10 band) sehingga akuisisi data lebih cepat khususnya jika digunakan pada machine vision [10]. Pencitraan hiperspektral telah digunakan untuk mengklasifikasi kematangan buah aprikot [11], memprediksi sifat kimia dan sifat fisika buah seperti kandungan air, kandungan padatan terlarut, ph, untuk stroberi [12] dan tomat [13], dan mendeteksi kerusakan yang tidak terlihat pada buah kiwi [14].

Indonesia adalah salah satu negara pengekpor Crude Palm Oil (CPO) terbesar di dunia, namun berbagai permasalahan dapat mengancam keberlangsungan industri kelapa sawit indonesia. Salah satu permasalahan adalah kualitas CPO Indonesia yang masih di bawah standar Internasional sehingga kurang mampu bersaing dengan produsen CPO Malaysia dan negara lainnya. Salah satu faktor yang menyebabkan kualitas CPO Indonesia lebih rendah adalah kadar asam lemak bebas (free fatty acid) yang masih tinggi [15]. Kadar asam lemak bebas yang tinggi dapat disebabkan oleh beberapa faktor. Faktor utamanya adalah tingkat kematangan dan keadaan atau kualitas TBS sebelum masuk pada proses perebusan yang beragam dimana proses penyortiran dan grading masing dilakukan secara tradisional dan manual serta tidak menyeluruh, tradisional mengandalkan pemanen dan grader yang berpengalaman, serta berdasarkan standar yang berbeda-beda untuk setiap perusahaan kelapa sawit [16]. Sortasi dan grading mengunakan metode nondestruktif seperti metode pencitraan hiperspektral sangat diperlukan dalam rangka menjaga keberlangsungan indusi sawit Indonesia dan menjaga mutu CPO yang diekspor.

Kematangan buah pada tandan buah segar (TBS) kelapa sawit dapat ditentukan secara tradisional mengunakan perubahan warna buah dan jumlah buah yang lepas atau membrondol dari dati tandan. Tingkat kematangan TBS yang optimal yaitu TBS dengan kadar minyak di atas $20 \%$ dan kadar asam lemak bebas di bawah $5 \%$. Perubahan warna buah kelapa sawit khususnya varitas Tenera saat mentah berwarna hitam, kemudian berubah menjadi ungu hingga merah saat matang, dan jingga ketika terlalu matang. Berdasarkan jumlah buah yang lepas, tingkat kematangan TBS dinyatakan dalam fraksi Fraksi kematangan terdiri dari 7 kelas yaitu: F00, F0, F1, F2, F3, F4, dan F5 dimana F00 dianggap sangat mentah dimana tidak ada buah yang membrondol, diikuti oleh F0 dan F1 yang dianggap kurang matang. Fraksi F2 dan F3 adalah fraksi yang disebut matang, buah berwarna kemerahan dan mengkilat, 1-5 buah membrondol. Fraksi F4 dan F5 disebut fraksi lewat matang dimana sebagian besar buah berwarna jingga, dan lebih banyak buah membrondol, dimana F5 lewat matang dengan buah bagian dalam ikut membrondol [17].

Sifat fisika dan kimia buah kelapa sawit juga dipengaruhi oleh berbagai hal lainnya seperti keadaan lingkungan dan nutrisi tanaman kelapa sawit yang cukup. Karakteristik fisika lahan dari tanaman kelapa sawit merupakan faktor penting untuk budidaya tanaman kelapa sawit [18]. Jenis tanah mempengaruhi pertumbuhan tanaman kelapa sawit sehingga mempengaruhi TBS kelapa sawit yang dihasilkan. Jenis tanah dapat dibagi sebagai lahan gambut dan lahan mineral. Seperti diketahui, hampir $70 \%$ dari total gambut tropik dunia terdapat di Asia Tenggara terutama di Indonesia dan Malaysia. Karena keterbatasan lahan untuk pertanian, lahan gambut sering dikonversi menjadi lahan pertanian khususnya untuk perkebunan kelapa sawit. .Pertumbuhan tanaman kelapa sawit dilahan rawa gambut tergolong rendah karena kandungan nutrisinya. Lahan gambut didefinisikan sebagai lahan dengan tanah jenuh air, terbentuk dari endapan yang berasal dari penumpukkan sisa-sisa (residu) jaringan tumbuhan masa lampau yang melapuk. Kandungan $C$ organik yang tinggi $(\geq 18 \%)$ dan dominan berada dalam kondisi tergenang (an-aerob) menyebabkan karakteristik lahan gambut berbeda dengan lahan mineral, baik sifat fisik maupun kimianya [19]. Sifat fisik tanah gambut merupakan faktor yang sangat menentukan tingkat produktivitas tanaman yang diusahakan pada lahan gambut, karena menentukan kondisi aerasi, drainase, daya menahan beban, serta tingkat atau potensi degradasi lahan gambut [20].

Metode penyortiran TBS kelapa sawit berdasarkan tingkat kematangan (ripeness stage) dan sifat fisika dan kimia buah telah banyak dilakukan. Metode Computer Vision (CV) yang mengandalkan perekaman citra TBS oleh kamera digital dan program pengolahan citra telah banyak digunakan karena lebih sederhana. Metode ini telah digunakan untuk mengestimasi tingkat kematangan TBS kelapa sawit antara lain mengunakan color computer vision [21], mengunakan metode fluorosensi [22], pengolahan data dan program klasifikasi 
mengunakan jaringan syaraf tiruan [23]. Pengunaan metode pencitraan hiperspektral untuk TBS kelapa sawit juga telah mulai dilakukan mengunakan spectrograph specim beserta mengevaluasi kadar minyak buah [24]. Sistem kamera hiperspektral sederhana mengunakan spectrograph specim juga telah digunakan untuk TBS kelapa sawit yang diletakkan pada sebuah translation stage dan telah memperlihatkan perbedaan spektrum panjang gelombang antara tiga tingkat kematangan TBS dan perbedaan jenis varitas TBS [25].

Pada penelitian ini, metode pencitraan hiperspektral mengunakan spektrograph specim dan komponen lainnya digunakan untuk membedakan TBS dari tanah tumbuh yang berbeda yaitu lahan gambut dan lahan mineral. Pada pabrik kelapa sawit (PKS), TBS - TBS kelapa sawit dari kedua jenis lahan ini sering dicampur oleh penjual untuk memperoleh keuntungan dimana terdapat anggapan bahwa TBS dari tanah gambut mempunyai kualitas yang lebih rendah. Proses penyortiran secara nondestruktif seperti pencitraan hiperspektral diperlukan karena dapat mengakses karakteristik internal buah. Penelitian untuk membedakan karakteristik fisika dan optik TBS dari tanah tumbuh berbeda telah dilakukan mengunakan tiga metode yaitu secara manual dengan mengukur berat, panjang, lebar, dan diameter TBS, kemudian mengunakan teknik machine vision untuk memperoleh informasi warna, dan mengunakan sensor optik untuk memperoleh kandungan klorofil dan antosianin [26]. Penelitian ini bertujuan untuk membedakan TBS kelapa sawit berdasarkan tanah tumbuh dan tingkat kematangan TBS kelapa sawit. Tingkat kematangan berdasarkan klasifikasi secara tradisional (fraksi) dijustifikasi mengunakan kekerasan buah yang diukur secara destruktif, kalsifikasi juga didasarkan pada intensitas reflektansi dan panjang gelombang optimum yang diperoleh dari citra hiperspektral. Klasifikasi secara statistik dilakukan mengunakan unsupervised machine learning yaitu K-means Clustering [27].

\section{METODE PENELITIAN}

Metode yang dilakukan dalam penelitian ini adalah metode ekperimen mengunakan pencitraan hiperspektral untuk membedakan TBS dari tanaman kelapa sawit yang tumbuh dari lahan gambut dan lahan mineral. Penelitian ini dilakukan dalam delapan tahapan. Tahapan pertama dimulai dengan mempersiapkan alat dan bahan yang digunakan. Tahapan kedua adalah menyusun dan mengkarakterisasi sistem pencitraan hiperspektral [28], [29]. Tahapan ketiga yaitu persiapan sampel TBS. Tahapan ke empat adalah perekaman citra TBS mengunakan sistem pencitraan hiperspektral yang telah disusun. Tahapan selanjutnya adalah pengukuran kekerasan daging buah kelapa sawit menggunakan penetrometer manual. Tahap keenam adalah pengolahan citra buah dengan program Matlab untuk mendapatkan intensitas reflektansi rata-rata TBS kelapa sawit. Tahap ketujuh adalah menganalisa hubungan antara intensitas reflektansi dengan kekerasan buah dalam bentuk grafik dari dua tanah tumbuh berbeda yaitu tanah gambut dan tanah mineral, dan pada berbagai tingkat kematangan. Tahap terakhir adalah melakukan klasifikasi tingkat kematangan buah berdasarkan kekerasan dan intensitas reflektansi menggunakan $K$-means Clustering dengan program SPSS, selanjutnya menarik kesimpulan.

\subsection{Sistem Pencitraan Hiperspektral}

Sistem pencitraan hiperspektral yang digunakan adalah sistem line scan mengunakan berkas cahaya berbentuk garis [28] yang dibangun dengan susunan seperti pada Gambar 1 [29], [30]. Alat-alat yang digunakan adalah kamera CMOS monokrom (A), spektrograf ImSpector V10 (B), lensa kamera (C), sumber cahaya lampu halogen berbentuk garis dan catu daya (D), sistem kontrol Arduino (E), laptop (F). dan konveyor (G). Tinggi lensa dari alas konveyor adalah $90 \mathrm{~cm}$ dan jarak lensa ke sampel adalah $75-80 \mathrm{~cm}$. Sistem ini dilingkupi kotak hitam akrilik yang berfungsi untuk mengisolasi sistem dari cahaya luar. Sistem hiperspektral dan kotak hitam diberi penyangga dan terpisah dari konveyor agar getaran konveyor tidak menganggu pengambilan data (L).

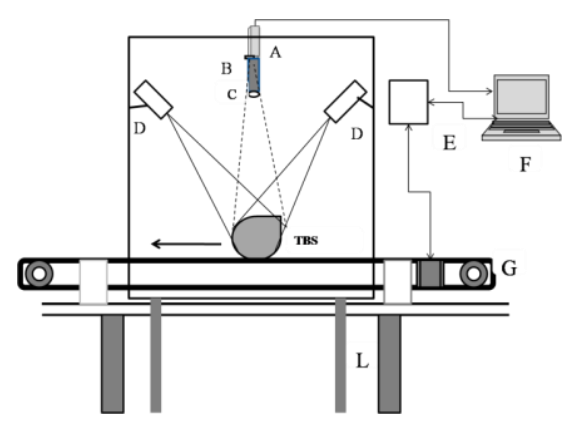

Gambar 1.a: Sistem Pencitraan Hiperspektral mengunakan Spektrograph Specim.

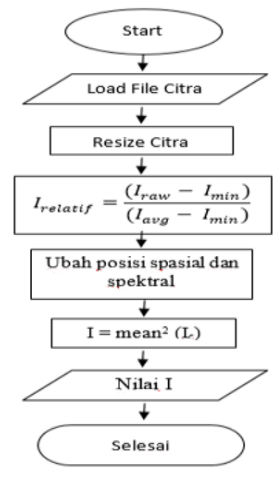

Gambar 1.b: Flowchart Pengolahan Citra

Gambar 1.a memperlihatkan skema sistem hiperspektral yang digunakan. Cahaya berbentuk garis dari lampu halogen beroperasi pada panjang gelombang $400 \mathrm{~nm}-1000 \mathrm{~nm}$ dengan daya $150 \mathrm{~W}$ mengenai TBS bagian atas 
pada sudut $45^{\circ}$, dua buah lampu Halogen yang dihubungkan dengan serat optik ke catu daya diletakkan pada dua sisi TBS. Cahaya dipantulkan oleh permukaan TBS yaitu oleh buah-buah kelapa sawit bagian luar ke kamera CMOS VNIR dengan ukuran sensor 1" melalui sebuah lensa $25 \mathrm{~mm}$ dan spektograf VNIR. Selanjutnya citra hiperspektral diperoleh dan direkam pada sebuah Laptop.

\subsection{Persiapan Sampel}

Sampel adalah tandan buah segar (TBS) kelapa sawit varietas Tenera 60 tandan dari tanah mineral dan 61 TBS dari tanah gambut dengan tiga tingkat kematangan yang sebelumnya ditentukan secara tradisional oleh mandor berpengalaman yaitu F0 dan F1 dikategorikan mentah, F2 dan F3 dikategorikan matang, F4 dikategorikan lewat matang. Sampel dari tanah gambut berasal dari perkebunan rakyat sedangkan yang tanah mineral berasal dari perkebunan agribisnis Universitas Riau. Sebelum perekaman, sampel dibersihkan mengunakan sikat dan ditandai dengan spidol pada pangkalnya sesuai fraksi kematangan. Sampel -sampel yang digunakan adalah sampel TBS yang baru dipanen dan tidak melebih waktu 24 jam setelah panen.

\subsection{Perekaman Citra}

Perekaman dilakukan dengan mematikan lampu ruangan dan menghidupkan lampu halogen pada sistem pencitraan hiperspektral. Sampel diletakkan di ujung konveyor, konveyor bergerak, TBS berhenti di tengah kotak akrilik. Pada penelitian ini, perekaman dilakukan pada saat konveyor diam, kemudian konveyor bergerak secara otomatis dan TBS kelapa sawit keluar dari kotak akrilik. Pada setiap tandan perekaman dilakukan dua kali yaitu bagian tengah depan dan belakang tandan. Perekaman dilakukan mengunakan software ikutan dari Kamera monokrom VNIR Sentech yang dipanggil melalui program Matlab. Perekaman citra diset pada 250 frame per scan untuk setiap permukaan TBS. Beberapa step yang di lakukan dalam merekam citra Hyperspectral yaitu membuka aplikasi St_Viewer yang berfungsi sebagai pengatur konfigurasi kamera yang terhubung ke Matlab, setelah selesai mengatur konfigurasi kamera, tutup aplikasi St_Viewer kemudian buka aplikasi matlab. Citra hiperspektral dari TBS direkam mengunakan program acquisition tool dengan cara mengetik perintah imaqtool pada command window.

Kalibrasi yang pertama adalah mengkarakterisasi sistem pencitraan hiperspektral yang diperlukan untuk memastikan orientasi spektrometer dengan sensor kamera mengunakan sinar laser merah dan hijau, citra sinar laser tersebut akan memperlihatkan dua garis yang berhubungan dengan sumbu vertikal tampilan layar Matlab di laptop atau desktop yaitu sumbu panjang gelombang yang dibagi bagian bawah sebagai $400 \mathrm{~nm}$ dan bagian atas $100 \mathrm{~nm}$. Kalibrasi berikutnya adalah merekam citra white dan dark yang diperlukan untuk memperoleh citra yang bebas dari cahaya latar. Ini dilakukan mengunakan sebuah papan putih terkalibrasi (Gigaoptik) berukuran $10 \mathrm{~cm}$ x $5 \mathrm{~cm}$ yang disebut white reference yang diletakkan diatas salah satu TBS. Kalibrasi mengunakan dua citra yaitu citra white dari white reference dan citra gelap (dark) yang diambil dengan menutup kamera.

\subsection{Pengolahan Citra}

Pengolahan citra dilakukan dengan tahapan sebagaimana tergambar pada flowchart pengolahan citra yaitu gambar 1.b. Program yang digunakan dalam pengolahan data citra adalah Matlab R2015a. Pengolahan citra dilakukan mengunakan Program Matlab [29]. Sub-citra direkam dan disimpan dalam bentuk mat-file (.mat) dan diolah menggunakan software Matlab untuk mendapatkan intensitas reflektansi pada rentang panjang gelombang $400-1000 \mathrm{~nm}$. Citra yang direkam mempunyai resolusi 1024x1088 dalam format 4-D kemudian diperkecil menjadi setengah dari ukuran semula (resize dan reduce) dalam format 3-D. Kalibrasi citra dilakukan dengan mengurangi citra asli dengan citra hitam dan putih untuk menentukan intensitas reflektansi setiap piksel yang sebenarnya. Citra terekam didapatkan dalam bentuk data spektral dan spasial 3 dimensi $(\lambda$, x dan y). Citra tersebut diubah posisi spectral $\lambda$ dan spasial $x$, menjadi ( $x, y$ dan $\lambda$ ), kemudian ditentukan intensitas rata-rata dari sub citra pada panjang gelombang $400 \mathrm{~nm}-1000 \mathrm{~nm}$.

Algoritma K-Means adalah metode clustering yang tidak mengunakan hierarki (unsupervised machine leaning) dan mempartisi data yang ada ke dalam satu atau lebih cluster. Metode ini mempartisi data ke dalam cluster, sehingga daya yang memiliki karakteristik yang sama akan berada dalam 1 cluster. K means mengelompokkan data berdasar jarak dari tiap dokumen ke pusat cluster (centroid) yang sudah ditentukan sebanyak k, dan mengumpulkan data-data ke pusat cluster yang terdekat. Algoritma K-means [33].

\subsection{Pengukuran Kekerasan Buah}

Kekerasan buah (firmness, hardness) adalah sifat fisika buah yang berhubungan sangat erat dengan tingkat kematangan buah dan dapat diprediksi mengunakan pencitraan hiperspektral [31], [32]. Tingkat kematangan TBS kelapa sawit yang diklasifikasi secara tradisional oleh pemanen berpengalaman mengunakan perubahan warna dan fraksi kematangan perlu dikuantisasi melalui pengukuran tingkat kekerasan buah menggunakan penetrometer untuk memperoleh data tingkat kekerasan buah dalam bentuk angka dengan satuan $\mathrm{kg} / \mathrm{cm}^{2}$. Penetrometer yang digunakan adalah alat penetrometer buah Model GY-3. Setelah perekaman citra hiperspektral TBS kelapa sawit dilakukan, 5 buah sawit (fruitlet) dilepas dari TBS bagian tengah untuk setiap sampel dan setiap tingkat kematangan kemudian diberi label sesuai tingkat kematangan sebelum pengukuran. 
Sebelum pengukuran kekerasan, kulit buah dikupas sedikit. Beban pada penetrometer diatur dan jarum penunjuk skala kedalaman tusukan diatur pada angka nol. Waktu pengukuran adalah 2 detik. Brondolan buah kelapa sawit ditempatkan dibawah jarum sehingga ujung jarum menempel pada permukaan kulit buah. Tombol ditekan untuk memulai tusukan. Kemudian dibaca jauhnya skala penanda bergeser dari angka nol. Dilakukan pengukuran pada beberapa tempat (ujung, tengah dan pangkal buah) untuk mendapatkan nilai rataan kekerasan buah.

\section{HASIL DAN PEMBAHASAN}

\subsection{Spektrum Reflektansi}

Grafik intensitas reflektansi versus panjang gelombang dapat dihasilkan mengunakan program Matlab untuk mendapatkan nilai intensitas rata-rata pada rentang panjang gelombang $400 \mathrm{~nm}-1000 \mathrm{~nm}$ seperti di perlihatkan pada Gambar 2 dan 3. Gambar 2 dan 3 merupakan grafik hubungan antara intensitas refleksi terhadap panjang gelombang masing - masing pada TBS kelapa sawit tanah gambut dan mineral. Grafik ini menunjukkan bahwa pada TBS kelapa sawit dari tanah gambut terjadi absorbsi pada panjang gelombang $500 \mathrm{~nm}-600 \mathrm{~nm}$, dan intensitas reflektansi mengalami kenaikan mulai panjang gelombang 700nm sampai dengan 900nm. Pada TBS kelapa sawit tanah mineral, absorbsi juga terjadi pada panjang gelombang 500nm - 600nm, selanjutnya intensitas reflektansi mengalami kenaikan pada panjang gelombang 600nm sampai dengan 900nm. Absorbsi tersebut sesuai kandungan klorofil dan antosianin dari buah yang menyerap cahaya pada rentang panjang gelombang tersebut [22]. Berdasarkan intensitas reflektansi dari TBS kelapa sawit tanah gambut dan mineral, kedua grafik menunjukkan bentuk kurva yang sama pada tiap kematangan dan hasil yang sama secara keseluruhan yaitu intensitas reflektansi TBS kelapa sawit kurang matang memiliki intensitas reflektansi paling rendah, kemudian diikuti TBS kelapa sawit matang dan mentah. Ini dapat disebabkan kandungan klorofil dan antosianin yang masih tinggi pada keadaan mentah untuk kedua jenis TBS[26].

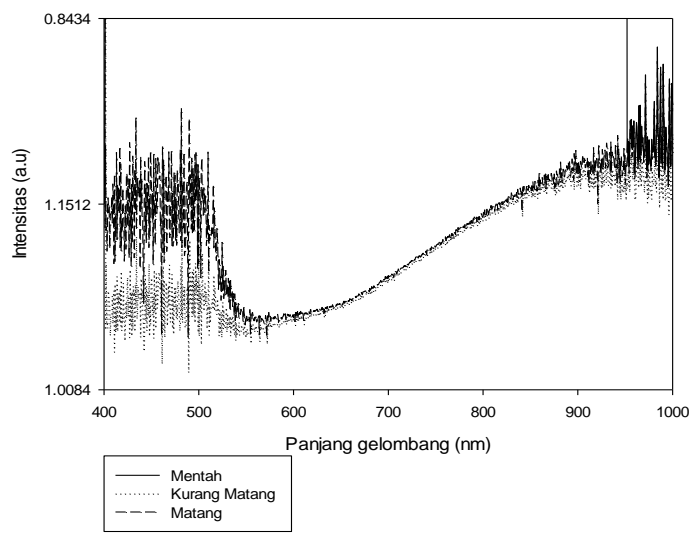

Gambar 2: Grafik Hubungan Intensitas Reflektansi terhadap Panjang Gelombang TBS Mineral

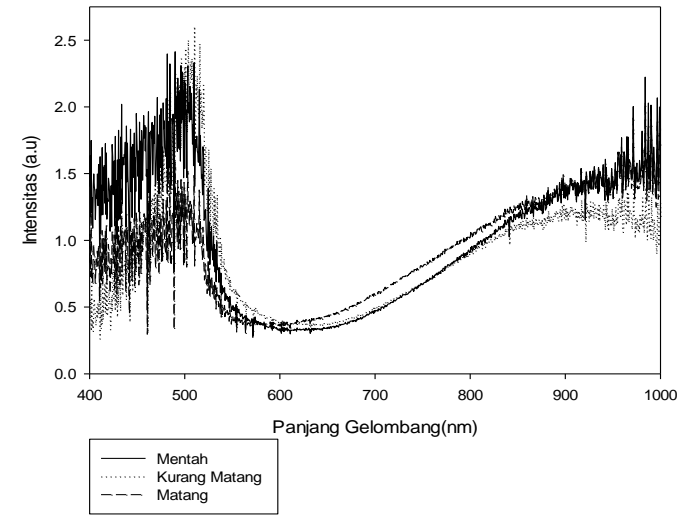

Gambar 3: Grafik Hubungan Intensitas Reflektansi terhadap Panjang Gelombang TBS Gambut

Pada Gambar 2 dan Gambar 3, Intensitas reflektansi pada rentang panjang gelombang 400-550 nm sangat tinggi. Ini disebabkan dua hal yaitu cahaya ruang yang masih mempengaruhi perekaman citra dimana bagian bawah kotak akrilik masih terbuka karena dilewati oleh konveyor. Alasan lainnya adalah citra white reference yang belum memadai karena ukurannya yang tidak menutupi permukaan TBS. Plat white reference yang digunakan (99\% reflektansi) merupakan produk Gigaoptik yang terkalibrasi. White reference yang ekonomis dapat dibuat mengunakan lapisan atau white coating pada papan triplek dengan permukaan yang halus kemudian dikalibrasi mengunakan lampu halogen (Edmundoptic). Pada Gambar 2 dan Gambar 3, rentang panjang gelombang diatas $900 \mathrm{~nm}$ tidak dapat digunakan karena terdapat derau (noise).

Pada rentang panjang gelombang 740nm $-760 \mathrm{~nm}$, perbedaan tanah tumbuh terlihat dari nilai intensitas reflektansi antara TBS kelapa sawit tanah gambut dan mineral dimana intensitas reflektansi TBS kelapa sawit tanah gambut lebih rendah daripada intensitas reflektansi TBS kelapa sawit tanah mineral. Pada tiga tingkat kematangan, mentah, kurang matang dan matang, TBS kelapa sawit dari tanah gambut dan mineral mengalami kenaikan intensitas reflektansi seiring dengan naiknya tingkat kematangan buah. Pada saat reflektansi meningkat, nilai absorbansi turun karena pigmen buah rendah. Tingginya reflektansi menunjukkan tingkat kematangan buah. Hubungan antara intensitas reflektansi dan tingkat kematangan ini digambarkan dengan baik pada rentang panjang gelombang 740nm-760nm. Hal ini sesuai dengan hasil penelitian [25], bahwa intensitas reflektansi meningkat selama panjang gelombang 700-880nm, dan pita spectral 750nm - 910nm membedakan 
tiga kategori tingkat kematangan TBS kelapa sawit. Begitu juga dengan hasil penelitian [24] dimana tingkat kematangan TBS kelapa sawit terbedakan pada panjang gelombang 740nm - 760nm.

\subsection{Tingkat Kekerasan Buah}

Tingkat kematangan yang diwakili oleh fraksi dikuantisasi melalui pengukuran kekerasan buah sehingga diperoleh nilai kematangan yang ditunjukkan oleh penetrometer. Gambar 4 dan 5 menunjukkan nilai kekerasan buah. Menurut [31], [32], mempunyai korelasi yang sangat tinggi dengan tingkat kematangan, sehingga metode pencitraan hiperspektral dapat digunakan untuk memprediksi kualitas buah berdasarkan kekerasan buah.

Pada kedua grafik terlihat bahwa kekerasan buah berkurang seiring bertambahnya tingkat kematangan buah. Buah mentah memiliki kekerasan sangat tinggi, dan berkurang kekerasannya pada buah matang. Hal ini menunjukkan kekerasan buah berbanding terbalik dengan tingkat kematangan buah. Buah matang memiliki kadar air lebih tinggi sehingga lebih lunak. Pada kedua grafik juga terlihat bahwa terjadi pergeseran dalam penentuan tingkat kematangan secara tradisional pada buah matang dan kurang matang, hal ini dikarenakan adanya perbedaan kecerahan warna dalam buah dalam satu TBS. Kedua grafik tersebut menunjukkan bahwa kekerasan TBS kelapa sawit dari tanah gambut lebih besar dari pada kekerasan TBS kelapa sawit dari tanah mineral.

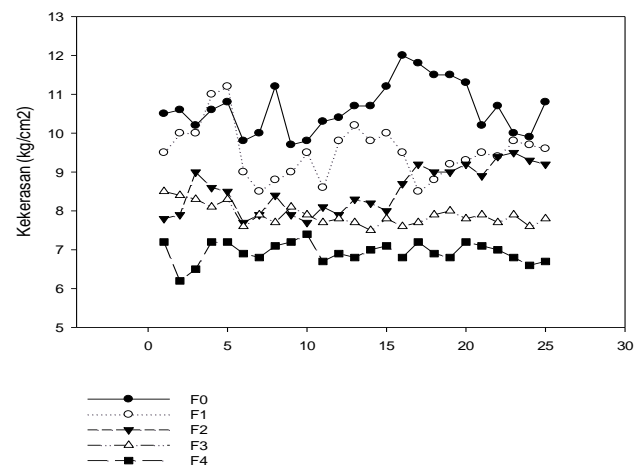

Gambar 4: Grafik Nilai Kekerasan TBS kelapa sawit gambut pada berbagai kematangan

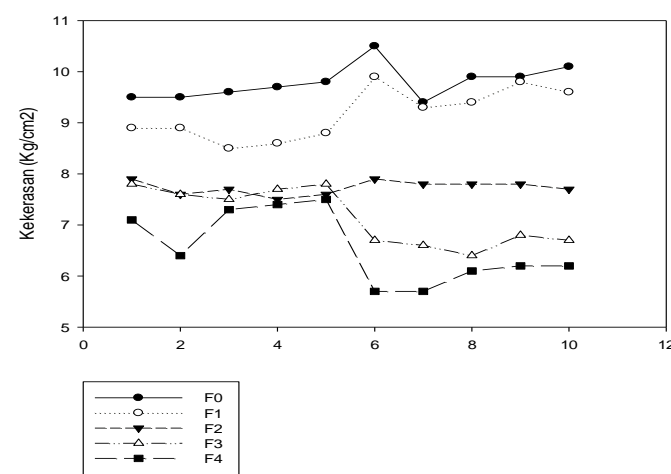

Gambar 5: Nilai Kekerasan TBS kelapa sawit mineral pada berbagai kematangan

\subsection{Klasifikasi Kematangan}

Untuk mengklasifikasi TBS berdasarkan tingkat kematangan, intensitas reflektansi representatif dipilih pada panjang gelombang $880 \mathrm{~nm}$ untuk TBS kelapa sawit mineral dan pada panjang gelombang $725 \mathrm{~nm}$ untuk TBS kelapa sawit gambut. Dimana pada panjang gelombang tersebut tingkat kematangan TBS kelapa sawit terbedakan dengan sangat baik. Grafik hubungan intensitas reflektansi terhadap kekerasan buah TBS kelapa sawit diperlihatkan pada Gambar 6 untuk TBS kelapa sawit tanah mineral dan Gambar 7 untuk TBS kelapa sawit tanah gambut.

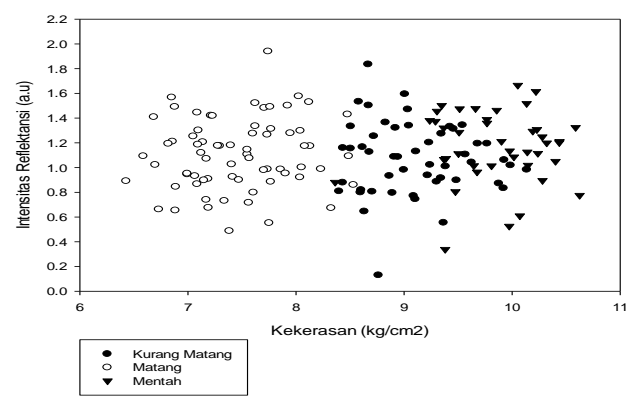

Gambar 6: Grafik Nilai Intensitas Reflektansi terhadap Kekerasan TBS kelapa sawit mineral pada berbagai kematangan

Gambar 6 menunjukkan bahwa intensitas reflektansi maksimum secara keseluruhan terdapat pada TBS kelapa sawit matang yaitu 1.9403 a.u pada kekerasan $7.74 \mathrm{~kg} / \mathrm{cm} 2$ dan intensitas reflektansi minimum terdapat pada TBS kelapa sawit kurang matang yaitu 0.4884 a.u pada kekerasan $8.76 \mathrm{~kg} / \mathrm{cm} 2$. Gambar 7 menunjukkan hubungan intensitas reklektansi terhadap kekerasan TBS kelapa sawit gambut pada berbagai kematangan dimana secara keseluruhan intensitas reflektansi maksimum yaitu sebesar 1.2933 a.u pada kekerasan $7.46 \mathrm{~kg} / \mathrm{cm} 2 \mathrm{dan}$ intensitas reflektansi minimum yaitu 0.2585 a.u pada kekerasan $7.39 \mathrm{~kg} / \mathrm{cm} 2$ adalah pada buah matang.

Secara keseluruhan dari TBS kelapa sawit mineral dan gambut, intensitas reflektansi maksimum konsisten berada pada TBS dengan kategori matang. Intensitas reflektansi minimum pada TBS kelapa sawit 
mineral berada pada TBS dengan kategori kurang matang, hal ini menunjukkan bahwa penurunan kadar pigmen buah mempengaruhi besarnya intensitas reflektansi. Hal ini tidak terlihat pada TBS kelapa sawit dari tanah gambut dimana mungkin terjadi pergeseran pada penentuan tingkat kematangan secara tradisional. Warna kulit buah yang gelap akan lebih banyak menyerap cahaya dari pada warna kulit buah yang lebih terang, sehingga intensitas reflektansi pada buah berwarna terang akan lebih tinggi dari pada buah berwana gelap.

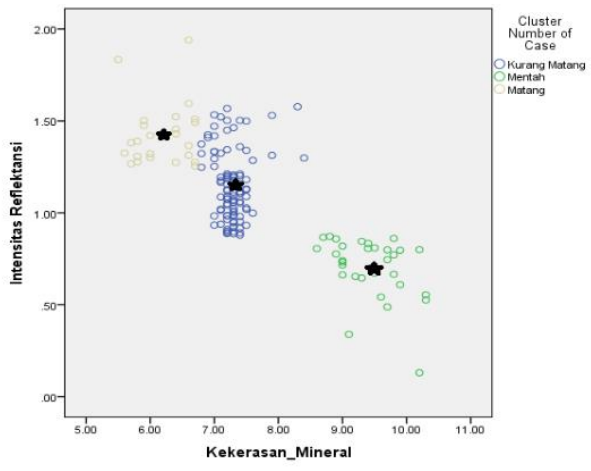

Gambar 8: Klasifikasi Tingkat Kematangan TBS kelapa sawit tanah mineral

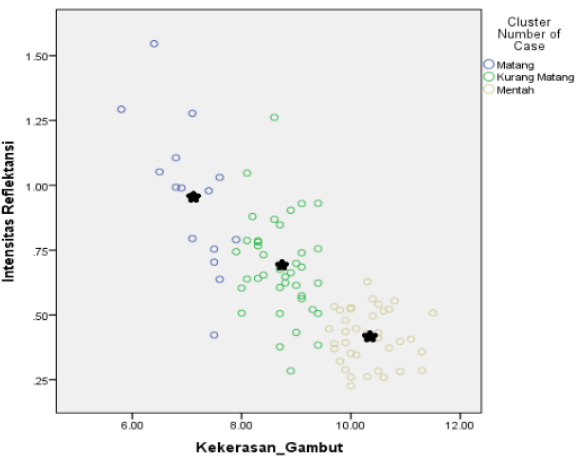

Gambar 9: Klasifikasi Tingkat Kematangan TBS kelapa sawit tanah gambut

Klasifikasi mengunakan $K$-mean clustering dilakukan dengan tujuan unuk mengelompokkan TBS kelapa sawit pada tingkat kematangan yang sesuai. Klasifikasi dibedakan menjadi 3 kluster yaitu mentah, kurang matang dan matang. Klasifikasi ini ditentukan dengan menggunakan K-means Clustering dari hubungan antara intensitas reflektansi terhadap kekerasan TBS Kelapa sawit seperti ditunjukkan pada Gambar 8 untuk klasifikasi TBS dari tanah Mineral dan Gambar 9 untuk klasifikasi TBS Kelapa sawit dari tanah Gambut.

Pada Gambar 8 centroid untuk kluster matang berada pada intensitas reflektansi 1.15 a.u dengan kekerasan $7.28 \mathrm{~kg} / \mathrm{cm} 2$. Centroid untuk kluster kurang matang berada pada intensitas reflektansi 0.7 a.u dengan kekerasan $9.44 \mathrm{~kg} / \mathrm{cm} 2$ dan centroid untuk kluster mentah berada pada intensitas reflektansi 1.43 a.u dengan kekerasan $6.19 \mathrm{~kg} / \mathrm{cm} 2$. Sedangkan pada gambar 9 centroid untuk kluster matang berada pada intensitas reflektansi 0.96 a.u dengan kekerasan $7.09 \mathrm{~kg} / \mathrm{cm} 2$. Centroid untuk kluster kurang matang berada pada intensitas reflektansi 0.69 a.u dengan kekerasan $8.72 \mathrm{~kg} / \mathrm{cm} 2$ dan centroid untuk kluster mentah berada pada intensitas reflektansi 0.42 a.u dengan kekerasan $10.33 \mathrm{~kg} / \mathrm{cm} 2$.

\section{KESIMPULAN}

Berdasarkan hasil penelitian pengunaan metode hiperspektral untuk membeda kan TBS kelapa sawit berdasarkan tanah tumbuh, beberapa hal dapat disimpulkan. Sistem pencitraan hiperspektral telah berhasil membedakan TBS yang berasal dari tanah tumbuh gambut dan mineral seperti di perlihatkan oleh spektrum reflektansi, tingkat kekerasan buah, tingkat kematangan dan klasifikasi mengunakan $K$ mean clustering. Intensitas reflektansi TBS kelapa sawit dari tanah gambut lebih tinggi daripada TBS kelapa sawit tanah mineral. Kekerasan TBS kelapa sawit tanah gambut lebih tinggi dari pada TBS kelapa sawit tanah mineral. Hubungan intensitas reflektansi dan panjang gelombang menunjukkan tingkat kematangan TBS kelapa sawit dari tanah mineral dan gambut berturutturut terbedakan dengan sangat baik pada panjang gelombang 880nm dan 725nm. Hubungan antara intensitas reflektansi dan tingkat kematangan ditunjukkan dengan baik pada rentang panjang gelombang 740nm-760nm, dimana tingginya intensitas reflektansi menunjukkan tingkat kematangan TBS. Metode non destruktif pencitraan hiperspektral ini dapat digunakan untuk menganalisa perbedaan intensitas reflektansi terhadap tingkat kematangan TBS kelapa sawit dari tanah tumbuh yang berbeda.

\section{UCAPAN TERIMAKASIH}

Penelitian ini di dukung oleh Universitas Riau dan sebagian dibiayai oleh BPDP melalui penelitian Grant Riset Sawit (PRJ No 33, 2018) untuk pengunaan sistem pencitraan hiperspektral specim V10. Ucapan terimakasih kepada Mahasiswa di lab Fotonik Universitas Riau yang telah membantu dalam penelitian ini.

\section{REFERENCES}

[1] J. AKodagali and S. Balaji, "Computer Vision and Image Analysis based Techniques for Automatic Characterization of Fruits A Review,” Int. J. Comput. Appl., 2012

[2] A. Bhargava and A. Bansal, "Fruits and vegetables quality evaluation using computer vision: A review," J. King Saud Univ. - Comput. Inf. Sci., 2018, doi: 10.1016/j.jksuci.2018.06.002. 
[3] B. Zhang, W. Huang, J. Li, C. Zhao, S. Fan, J. Wu, C, Liu, "Principles, developments and applications of computer vision for external quality inspection of fruits and vegetables: A review," Food Research International. 2014, doi: 10.1016/j.foodres.2014.03.012.

[4] M. P. Arakeri and Lakshmana, "Computer Vision Based Fruit Grading System for Quality Evaluation of Tomato in Agriculture industry," in Procedia Computer Science, 2016

[5] Abdellahhalimi, A. Roukhe, B. Abdenabi, and N. El Barbri, "Sorting dates fruit bunches based on their maturity using camera sensor system," J. Theor. Appl. Inf. Technol., 2013.

[6] J. A. Abbott, "Quality measurement of fruits and vegetables," Postharvest Biol. Technol., 1999, doi: 10.1016/S09255214(98)00086-6.

[7] P. Pathmanaban, B. K. Gnanavel, and S. S. Anandan, "Recent application of imaging techniques for fruit quality assessment," Trends in Food Science and Technology, Vol 94 pp 32-42, 2019,.

[8] A. Hussain, H. Pu, and D. W. Sun, "Innovative nondestructive imaging techniques for ripening and maturity of fruits A review of recent applications," Trends in Food Science and Technology, Vol 72, pp 144-152, 2018.

[9] Y. Lu, Y. Huang, and R. Lu, "Innovative hyperspectral imaging-based techniques for quality evaluation of fruits and vegetables: A review," Applied Sciences (Switzerland). 2017, doi: 10.3390/app7020189.

[10] R. Gruna, K. Vieth, M. Michelsburg, and F. Puente León, "Hyperspectral Imaging - From Laboratory to In-line Food Sorting," in 2nd International Workshop on Image Analysis in Agriculture 2010, 2010.

[11] J. Xue, S. Zhang, and J. Zhang, "Ripeness classification of Shajin apricot using hyperspectral imaging technique," Nongye Gongcheng Xuebao/Transactions Chinese Soc. Agric. Eng., 2015, doi: 10.11975/j.issn.10026819.2015.11.043

[12] G. El Masry, N. Wang, A. ElSayed dan M. Ngadi, "Hyperspectral imaging for non destructive determination of some quality attributes for strawberry,” J. Food Eng, vol 81 pp. 98-107, 2007.

[13] A. Rahman et al., "Nondestructive estimation of moisture content, $\mathrm{pH}$ and soluble solid contents in intact tomatoes using hyperspectral imaging," Appl. Sci., vol. 7 p109, 2017, doi: 10.3390/app7010109.

[14] [14]. Q. Lü and M. Tang, "Detection of Hidden Bruise on Kiwi fruit Using Hyperspectral Imaging and Parallelepiped Classification," Procedia Environ. Sci., 2012, doi: 10.1016/j.proenv.2012.01.404.

[15] M. Hudori, "Dampak Kerugian dan Usulan Pemecahan Masalah Kualitas Crude Palm Oil (CPO) di Pabrik Kelapa Sawit," Industrial Eng J. vol. 5(1) pp.35-40, 2016

[16] H. Ishak, M. Shiddiq, R. H. Fitra, and N. Z. Yasmin, "Ripeness Level Classification of Oil Palm Fresh Fruit Bunch Using Laser Induced Fluorescence Imaging,” J. Aceh Phys. Soc., 2019, doi: 10.24815/jacps.v8i3.14139.

[17] M. H. Razali, A. S. M. . Halim, and S. Roslan, “A review on crop plant production and ripeness forecasting,” Int. J Agric. Crop Sci., vol.4(2) pp. 54-36, 2012.

[18] D. Tyas and B. Hermawan, "Hubungan antara Beberapa Karakteristik Fisik Lahan dan Produksi Kelapa Sawit Relations between Physical Characteristics of Land and Palm Oil Production," Akta Agrosia, 2010.

[19] E. Nugraheni and N. Pangaribuan, "Pengelolaan lahan pertanian gambut secara berkelanjutan," Univ. Terbuka, Tangerang Selatan Univ. Pajajaran, 2008.

[20] A. Dariah, E. Maftuah, and Maswar, "Karakteristik Lahan Gambut," Pandu. Pengelolaan Berkelanjutan Lahan Gambut Terdegradasi, 2013.

[21] N. Fadilah, J. Mohamad-Saleh, Z. A. Halim, H. Ibrahim, and S. S. S. Ali, "Intelligent color vision system for ripeness classification of oil palm fresh fruit bunch," Sensors (Switzerland), 2012, doi: 10.3390/s121014179.

[22] M. H. M. Hazir, A. R. M. Shariff, M. D. Amiruddin, A. R. Ramli, and M. Iqbal Saripan, "Oil palm bunch ripeness classification using fluorescence technique,” J. Food Eng., 2012, doi: 10.1016/j.jfoodeng.2012.07.008.

[23] F. M. A. Mazen and A. A. Nashat, "Ripeness Classification of Bananas Using an Artificial Neural Network," Arab. J. Sci. Eng., 2019, doi: 10.1007/s13369-018-03695-5.

[24] P. Junkwon, T. Takigawa, H. Okomoto et al., "Hyperspectral imaging for nondestructive determination of internal qualities for oil palm (Elaeis guineensis Jacq. var. tenera)," Agric. Inf. Res., vol. 18 (3) pp. 130-141.

[25] O. M. Bensaeed, A. M. Shariff, A. B. Mahmud, H. Shafri, and M. Alfatni, "Oil palm fruit grading using a hyperspectral device and machine learning algorithm,” in IOP Conference Series: Earth and Environmental Science, pp. 1-22, 2014.

[26] M. H. M. Hazir and A. R. M. Shariff, "Oil palm physical and optical characteristics from two different: Planting materials,” Res. J. Appl. Sci. Eng. Technol., vo. 3 (9) pp. 953-952, 2011.

[27] J. Yadav and M. Sharma, “A Review of K-mean Algorithm,” Int. J. Eng. Trends Technol., 2013.

[28] H. Huang, L. Liu, and M. O. Ngadi, "Recent developments in hyperspectral imaging for assessment of food quality and safety," Sensors (Switzerland). 2014, doi: 10.3390/s140407248.

[29] F. Candra and S. A. R. S. Abu Bakar, "Hyperspectral imaging for predicting soluble solid content of starfruit," J. Teknol., vol.73(1) pp. 83-87, 2015, doi: 10.11113/jt.v73.3480.

[30] G. ElMasry and D. W. Sun, "Principles of Hyperspectral Imaging Technology," in Hyperspectral Imaging for Food Quality Analysis and Control, 2010.

[31] S.S. Sivakumar, J. Qiao, N. Wang, Y. Gariépy, G.S.V. Raghavan, and James McGill, "Detecting Maturity Parameters of Mango Using Hyperspectral Imaging Technique," 2013, doi: 10.13031/2013.21532.

[32] S. Fan, W. Huang, Z. Guo, B. Zhang, and C. Zhao, "Prediction of Soluble Solids Content and Firmness of Pears Using Hyperspectral Reflectance Imaging," Food Anal. Methods, 2015, doi: 10.1007/s12161-014-0079-1.

[33] L. Morissette and S. Chartier, "The k-means clustering technique: General considerations and implementation in Mathematica," Tutor. Quant. Methods Psychol., 2013, doi: 10.20982/tqmp.09.1.p015) 